\title{
Incorporation of Palm Oil Fuel Ash and Egg shell Powder as Supplementary Cementitious Materials in Sustainable Foamed Concrete
}

\author{
Ashfaque Ahmed JHATIAL, Wan Inn GOH*, Noridah MOHAMAD, Kim Hung MO, Samiullah SOHU
}

\begin{abstract}
The release of carbon dioxide $\left(\mathrm{CO}_{2}\right)$ during the production of cement and the increase in waste generation has allowed the construction to focus on sustainability by replacing cement with agricultural waste resources such as Palm Oil Fuel Ash (POFA) and Eggshell Powder (ESP). This experimental study focuses on developing sustainable foamed concrete incorporating high content of POFA and ESP as cement replacement with the aim of cement conversion, reduction in natural resources depletion, reduction of $\mathrm{CO}_{2}$ emissions and cleaner production. Cement was replaced using 30 and $35 \%$ POFA and 5 to $15 \%$ ESP by weight of cement. It was observed that the flowability decreased with the increase in the content of POFA and ESP; this is due to their ability to absorb water. It was also observed that $40 \%$ cement replacement achieved satisfactory compressive strength while the tensile stress loss was significant. This study confirmed that recycling and reusing of POFA and ESP are possible in foamed concrete which could be used for non-structural applications.
\end{abstract}

Keywords: cement conservation; high content cement replacement; solid waste management; sustainable concrete

\section{INTRODUCTION}

It has been reported by UN [1], that slightly more than $50 \%$ of the population are dwelling in these urbanized areas. To accommodate these migrations and to improve the existing infrastructures, rapid "concretization" has occurred. Concretization is a term used to describe the utilization of concrete as a building material in the construction of infrastructures. The feasibility, availability and durability have made concrete to become the most widely preferred construction and building material, and it is being used in vast applications ranging from construction of buildings to bridges, sidewalks and highway pavements to dams etc. [2], but it is also a very costly material according to market prices [3].

The normal-weight concrete (NWC) is the most widely used and preferred type of concrete in the world. But over the years, its increased self-weight on the structure and high consumption of raw materials have become its drawback. NWC whose density ranges from 2200 to $2600 \mathrm{~kg} / \mathrm{m}^{3}$ [4] exerts permanent stresses on the structure in the form of dead load. The increase in density of NWC, increases the self-weight which exerts permanent stresses on the structural building. To counter such stresses, adequate design of foundations is required thus increasing the constructional cost significantly. The ability to transfer heat through it is also another limitation associated with high density. The thermal conductivity has been reported to be $1.3 \mathrm{~W} / \mathrm{mK}$ of $2200 \mathrm{~kg} / \mathrm{m}^{3}$ density concrete [5]. This high value allows the heat exterior to transfer to the interior, which creates thermal discomfort for the residences. Therefore, to reduce the self-weight while also lower concrete's ability to transfer heat, researchers have focused their attention on the use of foamed concrete.

Foamed concrete is considered an alternative to NWC due to its lightweight and insulating properties. Foamed concrete, also known as cellular concrete, is a lightweight concrete which contains at least $20 \%$ air by volume [6]. Homogenous pore voids, which help in controlling the density of foamed concrete, are developed by the inclusion of air using the foaming agent [7-9]. Foamed concrete can be developed with varied density, reaching as low as 300 $\mathrm{kg} / \mathrm{m}^{3}$ and as high as $1840 \mathrm{~kg} / \mathrm{m}^{3}$ depending upon the addition of foam. Compared to NWC, the foamed concrete can be 23 to $87 \%$ lighter [10]. Being lighter allows foamed concrete to be used in the construction of high-rise buildings; the optimal building floor area is achieved with reduced self-weight. It also reduces the permanent stress on the foundations of the building; this reduces the constructional cost and saves material consumption.

Though the production of concrete has been increasing, it also possesses several sustainability issues, such as carbon footprint mainly due to cement and utilization of natural resources that need to be addressed. Though foamed concrete is sustainable concrete since it utilizes minimum natural resources compared to NWC by eliminating the use of coarse aggregates, it, however, still utilizes cement as the binder. The production of cement utilizes natural resources, and the burning of limestone in kiln releases a significant amount of greenhouse gas, Carbon Dioxide $\left(\mathrm{CO}_{2}\right)$. According to a report, approximately 5 to $7 \%$ of global $\mathrm{CO}_{2}$ gas is released by the cement industry [11]. In 2017, 4.10 giga tons of cement were produced [12], and according to Behnelal [11], each ton of cement produced generates an equal amount of $\mathrm{CO}_{2}$ gas.

Cement conservation is one of the most significant factors in achieving sustainability in the construction industry as well as the reduction of energy consumption and greenhouse gas emissions. The natural resources which are used in the production of both cement and concrete are limited; with the growing demand for construction, the extent of production of cement and concrete is alarmingly high. Cement is a vital ingredient of all types of concrete; thus, with the increase in construction using concrete, the demand for production of cement increases. Researchers [3, 13-20] have focused on the utilization of waste materials attempting to find alternative cementitious materials that can be used instead of cement and resolving the ever-growing environmental issues related to the generation of waste materials.

The increase in urbanization not only increased concretization but also increased the generation of byproducts. Wastes are those unintended but unavoidable, unwanted, or unusable materials which are generated due to the manufacturing or synthesis of something else. 
Malaysia is one of the leading exporters of Palm Oil, thus generates a massive amount of Palm related wastes, mainly Palm Oil Fuel Ash (POFA), while consumption of eggs, which are a cheap source of nutrition, produces eggshell waste. Eggshells and POFA are disposed into landfills which cause environmental and health risks to the nearby residents. Both POFA and eggshells have been individually utilized in concrete as supplementary cementitious materials (SCMs) as well as fine aggregates, but the utilization has been limited.

Malaysia is the leading palm oil producer and exporter in the world, generating approximately 4 million tonnes of a waste product known as POFA annually [21, 22], which is disposed as solid waste. POFA is significant waste that needs to be recycled. This hazardous material is usually sent to be disposed at landfills without any commercial gains. The continuous disposal in the landfills will lead to more environmental issues. To counter the environmental issues, several researchers over the years have attempted to reuse POFA sustainably, and it has been found that POFA contains pozzolanic properties so that it can be utilized as an alternative product in the construction industry. POFA being ash causes a nuisance to the environment. With the continuous increase in the production of palm oil in tropical countries, especially Malaysia, the amount of POFA generated increases adversely, creating health and environmental concerns [23]. Therefore, due to its pozzolanic nature, it contains high Silica content, and to minimize the dumping of POFA in open-air landfills, researchers have utilized POFA as supplementary cementitious material (SCM), replacing cement in concrete. Though it has been found that up to $20 \%$ cement content can be replaced by POFA successfully without losing strength $[24,25]$, a further increase in replacement shows a gradual loss in strength. This may be due to limited freely available calcium oxide $(\mathrm{CaO})$ that is required during the pozzolanic reaction. It is hypothesized that in order to enhance the pozzolanic activity of POFA further and increase its content, additional $\mathrm{CaO}$ in the form of eggshell is provided in concrete, as eggshells contain significantly high concentrations of $\mathrm{CaO}$, making it the most suitable material to be utilized along with POFA as cement replacement.

Eggshells are one of such wastes which require extensive research for their potential usage in concrete as supplementary material. The eggshell primarily contains calcium, magnesium carbonate (lime) and protein [26]. Malaysians consume approximately 2.8 million eggs daily, according to the report by Astro Awani [27]. The eggshells generally end up being disposed off in landfills without proper treatment. Due to their availability and chemical composition, eggshells have the potential to cause severe environmental pollution once disposed off in an open landfill; thus, proper management and treatment are required [28]. It has been found that ESP has a positive effect on strength characteristics when it is mixed with concrete. Eggshells have been found to have a high content of calcium and show similar chemical composition not only as limestone [29] but almost identical to that of ordinary Portland cement (OPC).

Though managing waste properly is critical in building sustainable and liveable cities, yet traditional methods put a financial burden on the economy of the country [30].
Considering the emission of $\mathrm{CO}_{2}$, this research aims at partially substituting cement with waste products, which also cause environmental problems due to their disposal and scarcity of land. The partial supplement of cement will help in reducing the production of cement and will ultimately reduce the emission of $\mathrm{CO}_{2}$. At the same time, it also contributes towards the reduction of ESP and POFA's negative impact on the environment and provides a beneficial means instead of being disposed off in landfills. It will be able to provide useful information and exposure in the thermal properties of sustainable foamed concrete since the data and statistic in this field is still limited. In addition, this study can help in providing idea and vision to other researchers or engineers in the potential application of sustainable foamed concrete.

This experimental work aims to develop a sustainable foamed concrete by incorporating waste materials (POFA and ESP) as partial cement replacement such that a sustainable eco-friendly concrete is developed which will be lightweight, thermal insulating and will utilize waste materials in an attempt to conserve natural resources and reduce the $\mathrm{CO}_{2}$ gas emissions.

\section{MATERIALS AND METHODOLOGY 2.1 Materials}

OPC, sand, foaming agent and water are the main ingredients required to produce foamed concrete. Since sustainable foamed concrete is a type of foamed concrete, the same ingredients are used in its development, while the only difference is that OPC is partially replaced using waste materials. The sand-binder ratio used for this study was $2: 1$, the foam was pre-generated using 1:20 (foaming agent to water) ratio, while 0.55 water-binder $(w / b)$ ratio was used. The sand, used as fine aggregates, was sieved through $4.75 \mu \mathrm{m}$ sieve and oven-dried before being packed in plastic bags such that it does not absorb any moisture.

POFA, collected from Ban Dung Palm Oil Mill, Parit Sulong, Malaysia, is a solid waste, is kept in the open air; therefore, it may absorb moisture and impurities. Therefore, POFA was sieved through $300 \mu \mathrm{m}$ to remove any impurities it may contain and was oven-dried at a temperature of $105^{\circ} \mathrm{C} \pm 5^{\circ} \mathrm{C}$ for 24 hours to remove any moisture content that POFA may have absorbed as suggested by Liu et al. [31]. Afterwards, POFA was ground using Los Angeles Abrasion Machine for 2 hours.

The raw eggshells were collected from different food stalls, restaurants, and bakeries. The collected raw eggshells contained yellowish fluid, which was removed by washing the raw eggshells with potable water. The cleaned eggshells were then oven-dried to remove moisture for 24 hours at a temperature of $105^{\circ} \mathrm{C} \pm 5^{\circ} \mathrm{C}$ as suggested by $\mathrm{Yu}$ et al. [32]. The moisture-dried eggshells were ground using Los Angeles Abrasion Machine for 2 hours. The purpose of grinding in Los Angeles machine was to increase the reactivity of materials.

\subsection{Physical and Chemical Properties of Binders}

The particle size distribution curve (Fig. 1) shows that both ESP and POFA are well ground cementitious materials. The results showed that all ESP particles passed through $75 \mu \mathrm{m}$. Approximately $95.95 \%$ of ESP particles 
were observed to pass through $45 \mu \mathrm{m}$, while their mean size was determined to be $11.4 \mu \mathrm{m}$. The POFA particles showed that approximately $84.23 \%$ passed through $45 \mu \mathrm{m}$, while their mean size was $19.6 \mu \mathrm{m}$. On the fine side, it was observed that approximately $16.63 \%$ of the ESP particles and $6.29 \%$ of POFA particles were smaller than $2 \mu \mathrm{m}$ while the cement that was used in this research had $7.29 \%$ particles which were smaller than $2 \mu \mathrm{m}$ and $96.47 \%$ of particles passed through $45 \mu \mathrm{m}$. The mean particle size of cement was determined to be $18.4 \mu \mathrm{m}$.

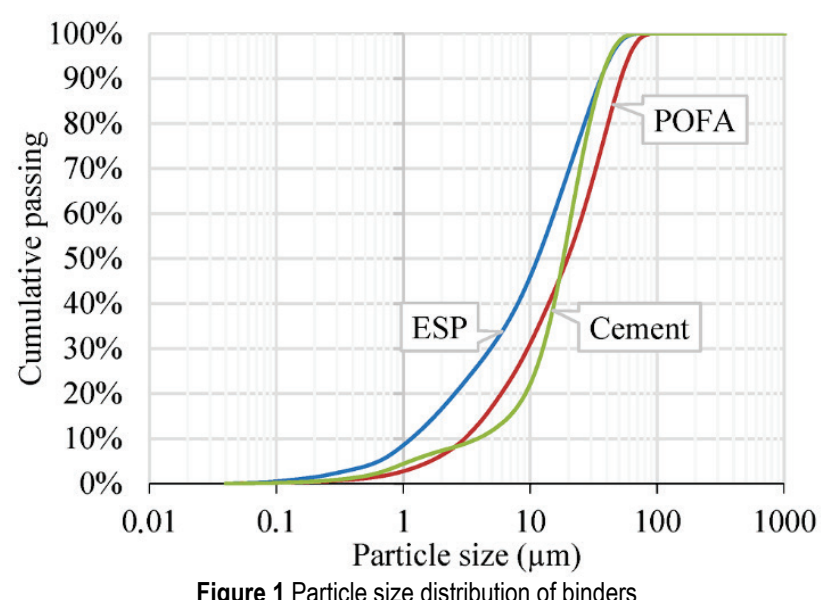

Figure 1 Particle size distribution of binders

Table 1 Physical properties of binder materials

\begin{tabular}{|l|c|c|c|}
\hline \multicolumn{1}{|c|}{ Physical Properties } & OPC & POFA & ESP \\
\hline$\%$ Passing through $45 \mu \mathrm{m}(\mathrm{no} .325)$ sieve & 96.47 & 84.23 & 95.95 \\
\hline Median Particle Size, $\mathrm{d} 50 / \mu \mathrm{m}$ & 18.4 & 19.6 & 11.4 \\
\hline Specific Surface Area $/ \mathrm{cm}^{2} / \mathrm{g}$ & 4870.81 & 4532.38 & 9740.14 \\
\hline Specific Gravity & 3.14 & 2.12 & 2.34 \\
\hline
\end{tabular}

The surface area of POFA was determined to be approximately $4532 \mathrm{~cm}^{2} / \mathrm{g}$ which is almost similar to the surface area of OPC, $4870 \mathrm{~cm}^{2} / \mathrm{g}$. The surface area of ESP was much higher, $9740 \mathrm{~cm}^{2} / \mathrm{g}$, as shown in Tab. 1. This much higher surface area can be due to the open porosity of the ground ESP. The surface area measurements include not only the external but also the open internal surface area of the particles. Therefore, they can be strongly affected by the fine porosity of the fines, which can result from continuous grinding of ESP.

X-Ray Fluorescence (XRF) test was conducted to study and determine the elemental chemical composition of the material. Since waste materials are used as cement replacement in the development of sustainable foamed concrete, therefore, the chemical analysis of such materials is required. The chemical composition of POFA and ESP, as well as OPC, is shown in Tab. 2.

Table 2 Chemical Composition of Binder Materials

\begin{tabular}{|l|c|c|c|}
\hline \multicolumn{1}{|c|}{ Chemical Composition } & OPC & POFA & ESP \\
\hline Calcium Oxide $(\mathrm{CaO})$ & $63.95 \%$ & $8.10 \%$ & $88.76 \%$ \\
\hline Silica dioxide $\left(\mathrm{SiO}_{2}\right)$ & $20.61 \%$ & $51.83 \%$ & $1.63 \%$ \\
\hline Aluminium $\mathrm{Oxide}_{2}\left(\mathrm{Al}_{2} \mathrm{O}_{3}\right)$ & $3.95 \%$ & $2.32 \%$ & - \\
\hline Iron oxide $\left(\mathrm{Fe}_{2} \mathrm{O}_{3}\right)$ & $3.46 \%$ & $7.60 \%$ & $0.05 \%$ \\
\hline Magnesium oxide $(\mathrm{MgO})$ & $1.93 \%$ & $3.13 \%$ & $0.91 \%$ \\
\hline Potassium oxide $\left(\mathrm{K}_{2} \mathrm{O}\right)$ & - & $13.72 \%$ & $0.24 \%$ \\
\hline Carbon $(\mathrm{C})$ & - & $0.28 \%$ & - \\
\hline Sulphur oxide $\left(\mathrm{SO}_{3}\right)$ & $3.62 \%$ & $2.23 \%$ & $0.81 \%$ \\
\hline Phosphorus pentoxide $\left(\mathrm{P}_{2} \mathrm{O}_{5}\right)$ & - & $4.30 \%$ & - \\
\hline LOI & 2.18 & 6.29 & 7.6 \\
\hline
\end{tabular}

From Tab. 2, it can be noticed that POFA contains moderate amount of silica, while a significantly small amount of $\mathrm{CaO}$ and $\mathrm{K}_{2} \mathrm{O}$ is also present. Previously it has been found that finely produced pozzolanic materials enhance the reactivity. All pozzolans that are going to be utilized as cement replacement in concrete should conform to the requirements which are prescribed by ASTM C61819 [33]. The sum of $\mathrm{SiO}_{2}+\mathrm{Al}_{2} \mathrm{O}_{3}+\mathrm{Fe}_{2} \mathrm{O}_{3}$ of POFA is approximately $61.75 \%$, which according to ASTM C61819 is less than $70 \%$ but more than $50 \%$, thus this POFA can be categorized as Class-C pozzolanic.

\subsection{Sample Preparation}

In this experimental investigation, the sustainable foamed concrete was cast based on the target wet density of $1900 \mathrm{~kg} / \mathrm{m}^{3}$. The control foamed concrete specimen was cast for comparison. The amounts of $30 \%$ and $35 \%$ POFA were used to replace cement while ESP content was varied from $5 \%$ to $15 \%$ by weight as shown in Tab. 3 .

Table 3 Mix Proportions and quantities required to produce $1 \mathrm{~m}^{3}$ sustainable foamed concrete

\begin{tabular}{|c|c|c|c|c|c|c|c|c|c|}
\hline \multirow{2}{*}{ Mix Proportion } & \multicolumn{3}{|c|}{$\%$ of Binder Content } & \multicolumn{6}{|c|}{ Amount of Quantities } \\
\hline & Cement & POFA & ESP & Cement / kg & POFA / kg & $\mathrm{ESP} / \mathrm{kg}$ & Sand / kg & Water / litres & Foam / litres \\
\hline M0 & $100 \%$ & $0 \%$ & $0 \%$ & 535.21 & 0 & 0 & 1070.42 & 294.37 & 125.06 \\
\hline M1 & $65 \%$ & $30 \%$ & $5 \%$ & 347.89 & 160.56 & 26.76 & 1070.42 & 294.37 & 125.06 \\
\hline M2 & $60 \%$ & $30 \%$ & $10 \%$ & 321.13 & 160.56 & 53.52 & 1070.42 & 294.37 & 125.06 \\
\hline M3 & $55 \%$ & $30 \%$ & $15 \%$ & 294.37 & 160.56 & 80.28 & 1070.42 & 294.37 & 125.06 \\
\hline M4 & $60 \%$ & $35 \%$ & $5 \%$ & 321.13 & 187.32 & 26.76 & 1070.42 & 294.37 & 125.06 \\
\hline M5 & $55 \%$ & $35 \%$ & $10 \%$ & 294.37 & 187.32 & 53.52 & 1070.42 & 294.37 & 125.06 \\
\hline M6 & $50 \%$ & $35 \%$ & $15 \%$ & 267.61 & 187.32 & 80.28 & 1070.42 & 294.37 & 125.06 \\
\hline
\end{tabular}

The dry binder materials and sand were put in the rotary concrete mixer and left to mix for about $3 \mathrm{~min}$ so that the binders and sand are mixed thoroughly. Afterwards, the measured water as per the $w / b$ ratio was gradually added and left to mix for another 5 minutes. Before adding the foam, the density of the wet mix was checked using density bottle. Once the density of non-foam wet mix was measured, the pre-generated foam was added gradually to achieve the wet target density of sustainable foamed concrete. The density of the wet mix was measured after each time foam was added. Once the target density was achieved, the flowability was checked using j-ring test. The sustainable foamed concrete was then poured into the beforehand-prepared moulds and kept for 24 hours. Afterwards, the specimens were demoulded and kept for air-curing at ambient temperature. Specimens of $0.1 \mathrm{~m}$ cubes were cast to determine the compressive strength of sustainable foamed concrete which was carried out after 7and 28-days air-curing. Cylindrical specimens of $0.1 \times 0.2$ $\mathrm{m}$ height were prepared to determine the tensile strength as well as the modulus of elasticity. 


\section{RESULTS AND DISCUSSION}

\subsection{Effect on Flowability of concrete}

The effect of the addition of POFA and ESP on the flowability of foamed concrete was determined by J-Ring test, which was conducted in accordance with the guidelines prescribed in ASTM C 1621/C 1621M-17 [34]. The results obtained are tabulated in Tab. 4. The foamed concrete is a well-known type of concrete, which is highly flowable and self-levelling; this is proven in the workability test. Based on the result, the control sample of foamed concrete showed the maximum flowability. But with the gradual increase in cement replacement, the flowability decreased significantly. The flow of foamed concrete was restricted when POFA and ESP were added, the high surface area of both POFA and ESP particles are the main reason behind this restriction which require significantly more water to achieve ease in movement and rolling of particles over each other.

The combined high content $(50 \%)$ cement replacement saw the maximum decrease in flowability as the high content of POFA and ESP absorb more water. Though the flowability was reduced with increase in POFA and ESP contents, the difference between slump flow and J-ring flow was between 0 to $25 \mathrm{~mm}$ for all mix proportions, and no visible blockage was observed in any of the mixtures.

Table 4 Flowability Result of Sustainable Foamed Concrete

\begin{tabular}{|c|c|c|c|c|c|c|c|c|}
\hline \multirow{2}{*}{ Mix } & \multicolumn{3}{|c|}{ Slump flow $(\mathrm{mm})$} & \multicolumn{3}{|c|}{ J-ring flow (mm) } & \multirow{2}{*}{ Difference Between Slump and J-ring Flow } & \multirow{2}{*}{ Types of Blocking } \\
\hline & $d_{1}$ & $d_{2}$ & $\left(d_{1}+d_{2}\right) / 2$ & $d_{1}$ & $d_{2}$ & $\left(d_{1}+d_{2}\right) / 2$ & & \\
\hline M0 & 533 & 528 & 531 & 520 & 520 & 520 & 11 & No blocking \\
\hline M1 & 410 & 400 & 405 & 394 & 381 & 388 & 17 & No blocking \\
\hline M2 & 476 & 408 & 442 & 465 & 381 & 423 & 19 & No blocking \\
\hline M3 & 432 & 396 & 414 & 400 & 385 & 393 & 21 & No blocking \\
\hline M4 & 407 & 391 & 399 & 381 & 376 & 379 & 20 & No blocking \\
\hline M5 & 436 & 390 & 413 & 400 & 381 & 392 & 21 & No blocking \\
\hline M6 & 398 & 380 & 389 & 370 & 365 & 368 & 21 & No blocking \\
\hline
\end{tabular}

\subsection{Effect on Compressive Strength of concrete}

The average compressive strength is tabulated in Tab. 5 and illustrated in Fig. 2. The compressive strength test was done in accordance with BS EN 12390-3:2009 [35]. It can be observed that the control sample of foamed concrete achieved $17.1 \mathrm{MPa}$ compressive strength, a $12.57 \%$ increase in compressive strength is seen when M1 sample (total $35 \%$ ) is used to replace cement while a further increase in replacement gradually reduces the compressive strength. However 40\% cement replacement (M2 and M4) showed slightly higher compressive strength than the control sample.

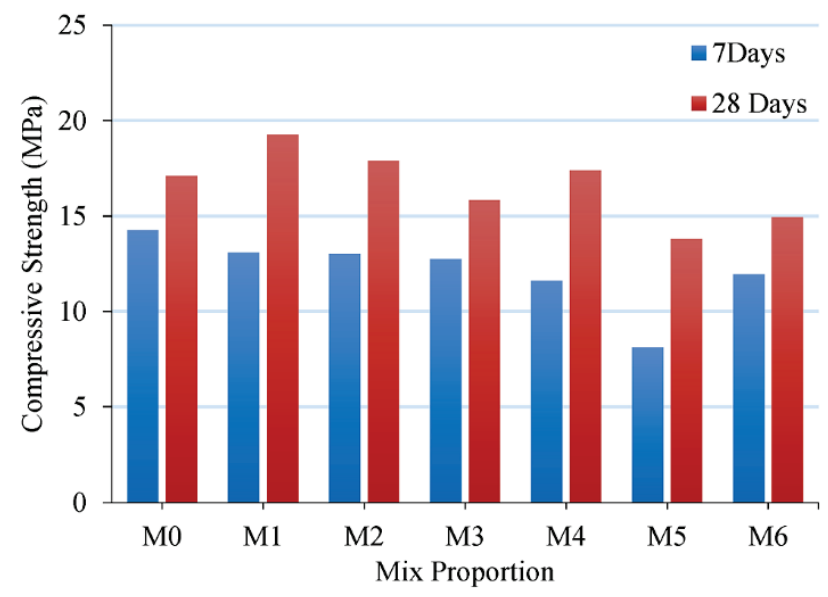

Figure 2 Average compressive strength of sustainable foamed concrete

The increase in the compressive strength is due to the increase in pozzolanic activity. POFA is well known pozzolanic material containing Silica Oxide $\left(\mathrm{SiO}_{2}\right)$, while ESP is known to be rich in $\mathrm{CaO}$. The $\mathrm{CaO}$ when in contact with water, turns into Calcium Hydroxide, $\mathrm{Ca}(\mathrm{OH})_{2}$, which is commonly known as lime, as shown in Eq. (1). When pozzolanic material comes in contact with water, a pozzolanic reaction occurs as shown in Eq. (2), during which lime is consumed to develop additional calciumsilicate-hydride (C-S-H) gels which are responsible for achieving the strength.

$\mathrm{CaO}+\mathrm{H}_{2} \mathrm{O} \rightarrow \mathrm{Ca}(\mathrm{OH})_{2}$

$\mathrm{Ca}(\mathrm{OH})_{2}+\mathrm{SiO}_{4}+\mathrm{H}_{2} \mathrm{O} \rightarrow \mathrm{CaH}_{2} \mathrm{SiO}_{4} \cdot 2 \mathrm{H}_{2} \mathrm{O}$

Table 5 Average compressive strength of sustainable foamed concrete

\begin{tabular}{|c|c|c|c|c|}
\hline \multirow{2}{*}{$\begin{array}{c}\text { Mix } \\
\text { Proportion }\end{array}$} & \multicolumn{2}{|c|}{$\begin{array}{c}\text { Average Compressive } \\
\text { Strength / MPa }\end{array}$} & \multicolumn{2}{|c|}{$\begin{array}{c}\text { Difference w.r.t to the } \\
\text { Control Sample / \% }\end{array}$} \\
\cline { 2 - 5 } & 7 Days & 28 Days & 7 Days & 28 Days \\
\hline M0 & 14.25 & 17.1 & --- & --- \\
\hline M1 & 13.07 & 19.25 & $-8.28 \%$ & $+12.57 \%$ \\
\hline M2 & 13 & 17.9 & $-8.77 \%$ & $+4.68 \%$ \\
\hline M3 & 12.73 & 15.83 & $-10.67 \%$ & $-7.43 \%$ \\
\hline M4 & 11.6 & 17.4 & $-18.60 \%$ & $+1.75 \%$ \\
\hline M5 & 8.1 & 13.8 & $-43.16 \%$ & $-19.30 \%$ \\
\hline M6 & 11.93 & 14.93 & $-16.28 \%$ & $-12.69 \%$ \\
\hline
\end{tabular}

Previously POFA has been used individually in concrete as a partial cement replacement, during the pozzolanic reaction. Cement can only provide a limited amount of free lime that POFA can consume and develop $\mathrm{C}-\mathrm{S}-\mathrm{H}$ gels. Therefore, its use as cement replacement has been restricted to $20 \%$, due to limited free lime provided by cement. Additional free lime added along with POFA during manufacturing of concrete can increase further content of POFA. This hypothesis is proved, as ESP has additional $\mathrm{CaO}$ which can be consumed by POFA during the pozzolanic reaction and increase the POFA content in concrete. The combined utilization of POFA and ESP not only increased the content of POFA that can be used in concrete but also increased the cement replacement content as $5 \%$ to $10 \%$ ESP can also be used along with increased POFA content as a cement replacement material. Thus total $40 \%$ of cement replacement is possible without losing compressive strength of concrete. The trend observed during this experimental work is similar to previous studies [36, 37]. 


\subsection{Effect on Split Tensile Strength of Concrete}

Tab. 6 shows the splitting tensile strength, which was done per BS EN 12390-6:2009 [38]. It is noticed that the control sample of foamed concrete achieved $2.07 \mathrm{MPa}$ tensile strength, while cement replacement significantly impacted the tensile strength of foamed concrete.

Table 6 Average splitting tensile strength of sustainable foamed concrete

\begin{tabular}{|c|c|c|}
\hline Mix Proportion & $\begin{array}{c}\text { Tensile Strength / } \\
\text { MPa }\end{array}$ & $\begin{array}{c}\text { Difference w.r.t. to the } \\
\text { Control Sample / \% }\end{array}$ \\
\hline M0 & 2.07 & --- \\
\hline M1 & 1.79 & $-13.53 \%$ \\
\hline M2 & 1.68 & $-18.84 \%$ \\
\hline M3 & 1.44 & $-30.43 \%$ \\
\hline M4 & 1.78 & $-14.01 \%$ \\
\hline M5 & 1.39 & $-32.85 \%$ \\
\hline M6 & 1.28 & $-38.16 \%$ \\
\hline
\end{tabular}

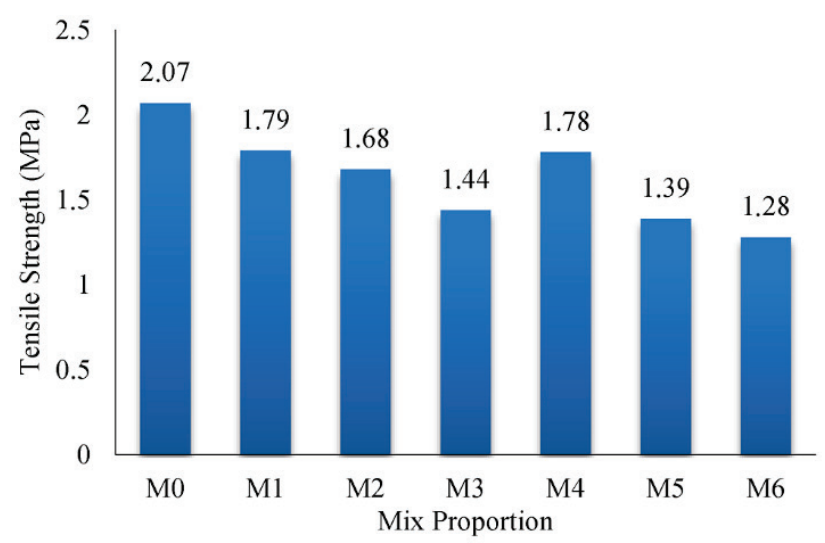

Figure 3 Average splitting tensile strength of sustainable foamed concrete

It is noticed that the tensile strength of foamed concrete samples containing POFA and ESP are lower than the control sample. Though some mix proportions which contained POFA and ESP resulted in higher compressive strength compared to the control sample, similar improvement is not visible for the tensile strength. It is a common fact that concrete is relatively strong under compression, while weak under tension, the main source of low tensile strength is the weak interfacial transition zone (ITZ) of concrete. It is possible that the high content of POFA and ESP in foamed concrete could not be effective in improving the ITZ between sand and binder matrix. The combined utilization of POFA and ESP, in contrast, relatively enhanced the compressive strength. This enhancement is most possibly due to the improvement mainly in the binder matrix of the foamed concrete.

\subsection{Compressive-Tensile Relationship}

A linear relationship was developed through statistical procedures to access the determined compressive and splitting tensile strength behaviour of foamed concrete incorporating different proportions of POFA and ESP, at the age of 28 days. $R^{2}$ value, determined through regression curve analysis, was considered as the relationship coefficient in this experimental work [39]. The regression curve line shows the relationship between the independent variable (compressive strength) and the dependent variable (splitting tensile strength) in the graph, as shown in Fig. 4. The developed equation, along with the $R^{2}$ coefficients is as provided below: $f_{\mathrm{t}}=0.1072 f_{\mathrm{cu}}-0.1463 \quad R^{2}=0.5196$

where: $f_{\mathrm{cu}}$ - the compressive strength, MPa; $f_{\mathrm{t}}$ - the split tensile strength, MPa.

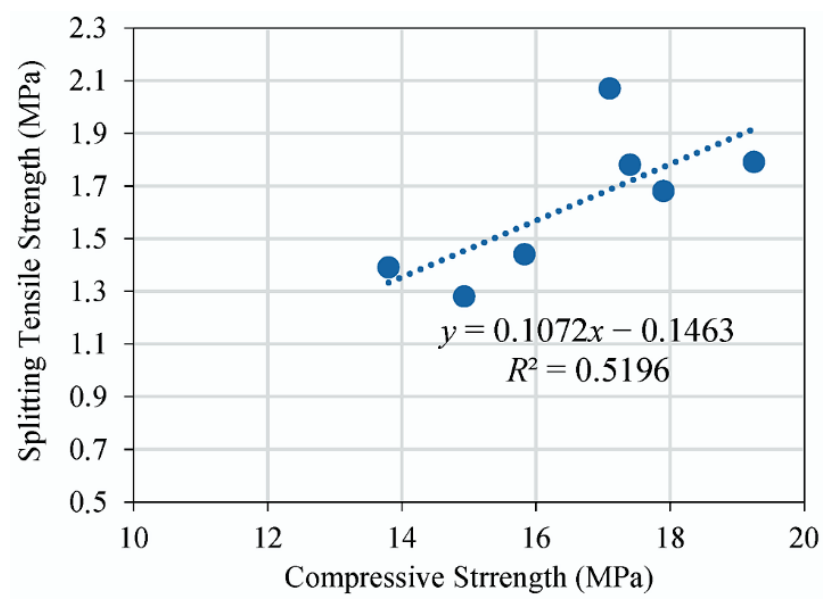

Figure 4 Compressive-tensile relationship of foamed concrete

\subsection{Modulus of Elasticity and Poisson's Ratio}

Modulus of elasticity and the Poisson's ratio are also important property indexes for foamed concrete. The modulus of elasticity indicates the resistance to deformation when stress is applied to any material; it also indicates the stiffness of the material. Concrete is known to be heterogeneous material whose strength is dependent on the relative proportion and modulus of elasticity of the aggregate. The average modulus of elasticity and Poisson's ratio of foamed concrete incorporating POFA and ESP are shown in Tab. 7.

Table 7 Average modulus of elasticity and Poisson's ratio

\begin{tabular}{|c|c|c|}
\hline Mix Proportion & Modulus of Elasticity / MPa & Poisson's Ratio \\
\hline M0 & 14394 & 0.25 \\
\hline M1 & 22258 & 0.27 \\
\hline M2 & 13202 & 0.15 \\
\hline M3 & 11037 & 0.11 \\
\hline M4 & 12666 & 0.34 \\
\hline M5 & 9447 & 0.12 \\
\hline M6 & 9304 & 0.13 \\
\hline
\end{tabular}

It was determined that the control sample of foamed concrete achieved $14394 \mathrm{MPa}$ modulus of elasticity. With the cement replacement, M1 achieved relatively higher modulus of elasticity and Poisson's ratio than the control sample. The modulus of elasticity results also present a similar trend, though the modulus of elasticity of all sustainable foamed concrete mixes is much higher than the control foamed concrete specimen. It has been reported previously that the modulus of elasticity of foamed concrete is directly proportional to the compressive strength [40-42]. M1 samples showed more increased modulus of elasticity than the other specimens along with higher tensile and compressive strengths.

According to Neville [3], NWC has Poisson's ratio ranging from 0.15 to 0.22 , lightweight aggregate concrete being at the lower end of the range. However, there has been no limited information regarding the Poisson's ratio range of foamed concrete. Previous researches [40, 43] have indicated that lightweight concrete has a Poisson's 
ratio ranging from 0.20 to 0.30 . It can be expected to have lower Poisson's ratio in lower density foamed concretes. The control mix achieved value in this range, while with the decrease in cement concrete the Poisson's ratio also decreased.

\subsection{Mirco-Structure Analysis}

A crushed sample of $5 \mathrm{~mm}$ collected from a sample which was tested for compressive strength was used to study the effect of POFA and ESP on the matrix of foamed concrete using the Scanning Electron Microscopy (SEM) shown in Fig. 5.

The microstructure analysis of control sample shows many air voids which allow it to entrap the air and help to slow down the heat transfer through the concrete medium. However, when the cement is partially replaced with POFA and ESP, the number of air voids in the matrix of foamed concrete is reduced but additional C-S-H gel is formed. The reduction in the quantity of air voids in the matrix of sustainable foamed concrete is due to the pozzolanic reaction and the nature of waste materials used.
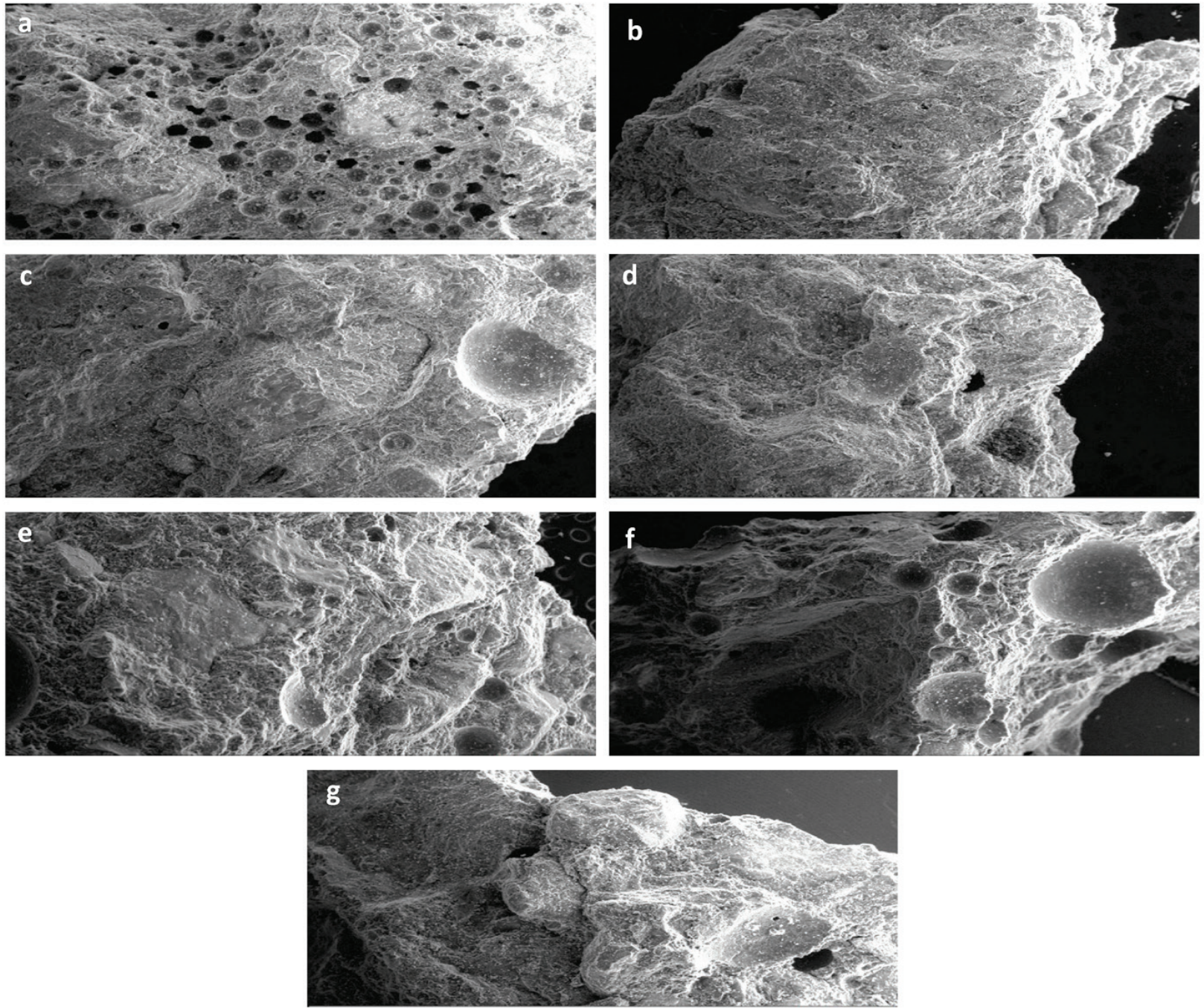

Figure 5 SEM images of (a) M0; (b) M1; (c) M2; (d) M3; (e) M4; (f) M5 and (g) M6 samples

The $\mathrm{Ca}(\mathrm{OH})_{2}$, generated during the hydration process which was triggered when water was added in the dry mix containing cement, reacts with silica provided by POFA activating another chemical reaction known as a pozzolanic reaction, in which the generated $\mathrm{Ca}(\mathrm{OH})_{2}$ is consumed to develop secondary C-S-H layers or gels. Thus, with the development of the secondary C-S-H layers, the voids are filled up voids that may be present between cement and aggregates as well as the air voids produced with the addition of foaming agent. This develops an interfacial bond between the paste and the aggregate, generating a stronger bond and ultimately increasing strength. It was observed that sustainable foamed concrete containing combined ash replacement of more than $40 \%$ achieved lower strength than the control sample, which may be attributed to the reduced amount of total C-S-H gel produced. Significantly reduced cement content limits the hydration process in the concrete, causing a lower amount of $\mathrm{Ca}(\mathrm{OH})_{2}$ generation, which is required for the pozzolanic activity to develop C-S-H layers. This adverse effect when excessive POFA is utilized as cement replacement has also been reported by other researchers $[22,44,45]$.

\section{CONCLUSION AND FUTURE RECOMMENDATIONS}

This experimental work highlighted the potential combined utilization of POFA and ESP to develop sustainable foamed concrete. It was observed that POFA and ESP are compatible cementitious resources since 
POFA, being pozzolanic material, requires $\mathrm{CaO}$ to consume and produce $\mathrm{C}-\mathrm{S}-\mathrm{H}$ gels. The additional $\mathrm{CaO}$ can be provided with the addition of ESP. The partial supplement of cement will help in reducing the production of cement and ultimately reduce the emission of $\mathrm{CO}_{2}$, while also contribute towards the reduction of ESP and POFA's negative impact on the environment and provide a beneficial means instead of being disposed off in landfills.

However, it was found that the flowability was adversely affected by the incorporation of waste materials. The workability decreases with the increase in cement replacement, due to the low specific gravity of both the waste materials which absorb most of the water added into the mix. A total of $40 \%$ combined utilization of POFA and ESP increases the compressive strength though it has an adverse effect on the tensile strength. Simultaneously, the increase in cement replacement content gradually reduced the modulus of elasticity of foamed concrete, only M1 sample containing 30\% POFA and 5\% ESP showed enhancement in modulus of elasticity. Based upon the results determined, it was observed that the foamed concrete incorporating high content cement replacement using POFA and ESP could be used as non-structural applications.

Furthermore, considering the importance of reduction of $\mathrm{CO}_{2}$ emissions and reducing dependency on cement, it is hereby recommended for future research to investigate the durability performance of foamed concrete incorporating POFA and ESP under aggressive conditions such as seawater exposure. Also, since foamed concrete is known to be excellent thermal insulating material, the effect on its thermal properties when POFA and ESP are incorporated should be studied.

\section{Acknowledgements}

The authors would like to appreciate and acknowledge the financial support received from Research Management Centre, Universiti Tun Hussein Onn Malaysia (UTHM), Malaysia, under RMC Research Fund Vot. E-15501 for this experimental project.

\section{REFERENCES}

[1] UN (2014). World urbanization trends 2014: Key facts", in World urbanization prospects: The 2014 revision highlights, United Nations, New York, 2014.

[2] Ghannam, S., Najm, H., \& Vasconez, R. (2016). Experimental study of concrete made with granite and iron powders as partial replacement of sand. Sustainable Materials and Technologies, 9, 1-6. https://doi.org/10.1016/j.susmat.2016.06.001

[3] Khalid, F. S., Mazenan, P. N., Ghani. A. H. A., Azmi, N. B., Juki, M. I., Shahidan, S., \& Ibrahim, M. H. W. (2018). An Utilization of Palm Fuel Ash (POFA) and Ceramic Waste as Cement Materials Replacement in Concrete Production. International Journal of Engineering \& Technology, 7(3.9), 89-92. https://doi.org/10.14419/ijet.v7i3.9.15284

[4] Neville, A. M. (2011). Properties of Concrete. Pearson Education Limited, Essex, 2011.

[5] Zahari, N. M., Rahman, I. A., \& Zaidi, A. M. A. (2009). Foamed Concrete: Potential Application in Thermal Insulation. Proceedings of MUCEET 2009 Malaysian Technical Universities Conference on Engineering and
Technology June 20-22, 2009, MS Garden, Kuantan, Pahang, Malaysia, 47-52.

[6] Harith, I. K. (2018). Study on polyurethane foamed concrete for use in structural applications. Case studies in construction materials, $8,79-86$. https://doi.org/10.1016/j.cscm.2017.11.005

[7] Goh, W. I., Mohamad, N., Abdullah, R., \& Samad, A. A. A. (2014). Compression test and finite element analysis of foamed concrete cube. Journal of Engineering and Technology, 5(1), 1-9.

[8] Tharkele, M. K. H. (2014). Experimental study on foam concrete. International Journal of Civil, Structural, Environmental and Infrastructure Engineering Research and Development, 4(1), 145-158.

[9] Abd, A. M. \& Abd, S. M. (2017). Modelling the strength of lightweight foamed concrete using support vector machine (SVM). Case Study in Construction Materials, 6, 8-15. https://doi.org/10.1016/j.cscm.2016.11.002

[10] Mohamad, N., Samad, A. A. A., Ali, N., Hadipramana, J., \& Jamaluddin, N. (2015). Performance of connected precast lightweight sandwich foamed concrete panel under flexural load. Jurnal Teknologi, 75(9), 111-115. https://doi.org/10.11113/jt.v75.5244

[11] Benhelal, E., Zahedi, G., Shamsaei, E., \& Bahadori, A. (2013). Global strategies and potentials to curb CO2 emissions in cement industry. Journal of Cleaner Production, 51, 142-161. https://doi.org/10.1016/j.jclepro.2012.10.049

[12] Ober, J. A. (2018). Mineral commodity summaries, 2018/U.S. Geological Survey. https://doi.org/10.3133/70194932

[13] Ghorbani, S., Taji, I., De Brito, J., Negahban, M., Ghorbani, S., Tavakkolizadeh, M., \& Davoodi, A. (2019). Mechanical and durability behaviour of concrete with granite waste dust as partial cement replacement under adverse exposure conditions. Construction and Building Materials, 194, 143152. https://doi.org/10.1016/j.conbuildmat.2018.11.023

[14] Kumar, V. P., Gunasekaran, K., \& Shyamala, T. (2019). Characterization study on coconut shell concrete with partial replacement of cement by Ggbs. Journal of Building Engineering, 100830. https://doi.org/10.1016/j.jobe.2019.100830

[15] Phul, A. A., Memon, M. J., Shah, S. N. R., \& Sandhu, A. R. (2019). GGBS and Fly Ash Effects on Compressive Strength by Partial Replacement of Cement Concrete. Civil Engineering Journal, 5(4), 913-921. https://doi.org/10.28991/cej-2019-03091299

[16] Hosen, M. A., Jumaat, M. Z., Alengaram, U. J., Sulong, N. R., \& Alsubari, B. (2019). Sustainable palm oil fuel ash mortar used as partial adhesive replacement in flexurally strengthened RC beams. Construction and Building Materials, 226, 507-523. https://doi.org/10.1016/j.conbuildmat.2019.07.222

[17] Prakash, R., Thenmozhi, R., Raman, S. N., \& Subramanian, C. (2019). Characterization of eco-friendly steel fiberreinforced concrete containing waste coconut shell as coarse aggregates and fly ash as partial cement replacement. Structural Concrete. https://doi.org/10.1002/suco.201800355

[18] Alsubari, B., Shafigh, P., Ibrahim, Z., \& Jumaat, M. Z. (2018). Heat-treated palm oil fuel ash as an effective supplementary cementitious material originating from agriculture waste. Construction and Building Materials, 167, 44-54. https://doi.org/10.1016/j.conbuildmat.2018.01.134

[19] Mangi, S. A., Ibrahim, M. H. W., Jamaluddin, N., Arshad, M. F., \& Shahidan, S. (2019). Performances of concrete containing coal bottom ash with different fineness as a supplementary cementitious material exposed to seawater. Engineering Science and Technology, an International Journal. https://doi.org/10.1016/j.jestch.2019.01.011 
[20] Mohamad, M. E., Mahmood, A. A., Min, A. Y. Y., \& AR, N. N. (2018). Palm Oil Fuel Ash (POFA) and Eggshell Powder (ESP) as Partial Replacement for Cement in Concrete. E3S Web of Conferences, 34, 01004. EDP Sciences. https://doi.org/10.1051/e3sconf/20183401004

[21] Zamri, N. A. B., Muthusamy, K., \& Ali, N. M. (2016). Durability of OPS lightweight aggregate concrete containing palm oil fuel ash after long term exposure in sulphate environment. The National Conference for Postgraduate Research 2016. University Malaysia Pahang, 525-528.

[22] Sooraj, V. M. (2013). Effect of palm oil fuel ash (POFA) on strength properties of concrete. International Journal of Scientific and Research Publications, 3(6), 1-7.

[23] Abdullah, K., Hussin, M. W., Zakaria, F., Muhamad, R., \& Hamid, Z. A. (2006). POFA: a potential cement replacement material in aerated concrete. Proceedings of the $6^{\text {th }}$ AsiaPacific Conference on Structural Engineering and Construction, Kuala Lumpur, Malaysia, September 5-6, 2006, 132-140. Retrieved from

http://eprints.utm.my/id/eprint/377/1/KAbdullah2006_POF APotentialPartialCementReplacement.pdf

[24] Chindaprasirt, P., Homwuttiwong, S., \& Jaturapitakkul, C. (2007). Strength and water permeability of concrete containing palm oil fuel ash and rice husk-bark ash. Construction and Building Materials, 21(7), 1492-1499. https://doi.org/10.1016/j.conbuildmat.2006.06.015

[25] Munir, A., Abdullah, H., Sofyana, I., \& Safwana (2015). Utilization of palm oil fuel ash (POFA) in producing lightweight foamed concrete for non-structural building material. Procedia Engineering, 125, 739-746. https://doi.org/10.1016/j.proeng.2015.11.119

[26] Gowsika, D., Sarankokila, S., \& Sargunan, K. (2014). Experimental investigation of egg shell powder as partial replacement with cement in concrete. International Journal of Engineering Trends and Technology, 14(2), 65-68. https://doi.org/10.14445/22315381/IJETT-V14P214

[27] Retrieved from

http://english.astroawani.com/malaysianews/malaysians-co nsume-1-8-million-chickens-daily-ahmad-shabery-111 491

[28] Raji, S. A. \& Samuel, A. T. (2015). Egg shell as a fine aggregate in concrete for sustainable construction. International Journal of Scientific \& Technology Research, 4(09), 8-13.

[29] Amu, O. O., Fajobi, A. B., \& Oke, B. O. (2005). Effect of Eggshell Powder on the Stabilizing Potential of Lime on an Expansive Clay Soil. Journal of Applied Sciences, 5(8), 1474-1478.

[30] Chandra Paul, S., Mbewe, P. B., Kong, S. Y., \& Šavija, B. (2019). Agricultural Solid Waste as Source of Supplementary Cementitious Materials in Developing Countries. Materials, 12(7), 1112, 1-20. https://doi.org/10.3390/ma12071112

[31] Liu, M. Y. J., Alengaram, U. J., Jumaat, M. Z., \& Mo, K. H. (2014). Evaluation of thermal conductivity, mechanical and transport properties of lightweight aggregate foamed geopolymer concrete. Energy \& Buildings, 72, 238-245. https://doi.org/10.1016/j.enbuild.2013.12.029

[32] Yu, T. Y., Ing, D. S., \& Choo, C. S. (2017). The effect of different curing methods on the compressive strength of eggshell concrete. Indian Journal of Science and Technology, 10(6), 1-4. https://doi.org/10.17485/ijst/2017/v10i6/111210

[33] ASTM C618-19 (2019). Standard Specification for Coal Fly Ash and Raw or Calcined Natural Pozzolan for Use in Concrete. ASTM International, West Conshohocken, PA.

[34] ASTM C1621 / C1621M-17 (2017). Standard Test Method for Passing Ability of Self-Consolidating Concrete by J-Ring, ASTM International, West Conshohocken, PA.
[35] BS EN 12390-3:2009 (2009). Testing Hardened Concrete. Compressive Strength of Test Specimens. British Standard Institution, London.

[36] Khalid, N. H. A., Rasid, N. N. A., Sam, A. M., Lim, N. H. A. S., Ismail, M., Zardasti, L., Mohamed, A., Majid, Z. A., \& Ariffin, N. F. (2018). Characterization of palm oil fuel ash and eggshell powder as partial cement replacement in concrete. In IOP Conference Series: Materials Science and Engineering, 431(3), 1-9. https://doi.org/10.1088/1757-899X/431/3/032002

[37] Mohamad, M. E., Mahmood, A. A., Min, A. Y. Y., \& Ar, N. N. (2018). Palm Oil Fuel Ash (POFA) and Eggshell Powder (ESP) as Partial Replacement for Cement in Concrete. E3S Web of Conferences, 34, 1-8. https://doi.org/10.1051/e3sconf/20183401004

[38] BS EN 12390-6:2009 (2009). Testing hardened concrete. Tensile splitting strength of test specimens. British Standard Institution, London.

[39] Mangi, S. A., Ibrahim, W., Haziman, M., Jamaluddin, N., Arshad, M. F., \& Mudjanarko, S. W. (2019). Recycling of Coal Ash in Concrete as a Partial Cementitious Resource. Resources, 8(2), 99, 1-10. https://doi.org/10.3390/resources8020099

[40] Ozlutas, K. Behaviour of Ultra-low Density Foamed Concrete. Doctoral dissertation, University of Dundee, 2015.

[41] Jones, M. R. \& Mccarthy, A. (2005). Preliminary views on the potential of foamed concrete as a structural material. Magazine of Concrete Research, 57(1), 21-31. https://doi.org/10.1680/macr.2005.57.1.21

[42] Jhatial, A. A., Goh, W. I., Mohamad, N., Hong, L. W., Lakhiar, M. T., Samad, A. A. A., \& Abdullah, R. (2018). The Mechanical Properties of Foamed Concrete with Polypropylene Fibres. International Journal of Engineering \& Technology, 7(3.7), 411-413.

[43] Lim, S. K., Tan, C. S., Lim, O. Y., \& Lee, Y. L. (2013). Fresh and hardened properties of lightweight foamed concrete with palm oil fuel ash as filler. Construction and Building Materials, 46, 39-47. https://doi.org/10.1016/j.conbuildmat.2013.04.015

[44] Muthusamy, K., Zamri, N., Zubir, M. A., Kusbiantoro, A., \& Ahmad, S. W. (2015). Effect of mixing ingredient on compressive strength of oil palm shell lightweight aggregate concrete containing palm oil fuel ash. Procedia Engineering, 125, 804-810. https://doi.org/10.1016/j.proeng.2015.11.142

[45] Awal, A. A. \& Hussin, M. W. (2011). Effect of palm oil fuel ash in controlling heat of hydration of concrete. Procedia Engineering, 14, 2650-2657.

https://doi.org/10.1016/j.proeng.2011.07.333

\section{Contact information:}

Ashfaque Ahmed JHATIAL, Lab Engineer, Master of Civil Engineering

Department of Civil Engineering,

Mehran University of Engineering and Technology,

Shaheed Zulfiqar Ali Bhutto Campus,

Khairpur Mirs', Sindh, Pakistan

E-mail: ashfaqueahmed@muetkhp.edu.pk

Wan Inn GOH, Lecturer, PhD in Civil Engineering

(Corresponding author)

Faculty of Civil Engineering and Built Environment,

Universiti Tun Hussein Onn Malaysia,

Parit Raja 86400, Batu Pahat, Johor, Malaysia

E-mail:wigoh@uthm.edu.my

Noridah MOHAMAD, Professor, PhD in Civil Engineering

Faculty of Civil Engineering and Built Environment,

Universiti Tun Hussein Onn Malaysia,

Parit Raja 86400, Batu Pahat, Johor, Malaysia

E-mail: noridah@uthm.edu.my 
Kim Hung MO, Lecturer, PhD in Civil Engineering

Department of Civil Engineering, Faculty of Engineering,

University of Malaya, 50603 Kuala Lumpur, Malaysia

E-mail:khmo@um.edu.my

Samiullah SOHU, Assistant Professor, $\mathrm{PhD}$ in Civil Engineering

Department of Civil Engineering,

Quaid-e-Awam University of Engineering, Science and Technology,

Larkana Campus, Larkana, Sindh, Pakistan

E-mail: engr.samiullah@quest.edu.pk 